\title{
Earnings Management and Audit Opinion
}

\author{
Elaheh Moazedi ${ }^{1} \&$ Ehsan khansalar ${ }^{2}$ \\ ${ }^{1}$ Department of Accounting, Qaenat Branch, Islamic Azad University, Qaenat, Iran \\ ${ }^{2}$ Departement of Accounting, Finance and Informatics, Kingston University, London, UK \\ Correspondence: Elaheh Moazedi, Department of Accounting, Qaenat Branch, Islamic Azad University, Qaenat, \\ Iran. Tel: 98-939-038-5088. E-mail: eli.birth1987@gmail.com
}

Received: November 16, 2015

Accepted: February 14, 2016

Online Published: March 25, 2016

doi:10.5539/ijef.v8n4p113

URL: http://dx.doi.org/10.5539/ijef.v8n4p113

\begin{abstract}
The subject of the present research is the study of the relationship between earnings management (accrual-based and real) and auditor's opinion. Alongside putting the control variables into consideration, this this paper studies the relationship between earnings management (accrual-based and real) and auditors' opinion. The purpose of this research is to examine the effect of income smoothing and manipulation on the opinion of independent auditors. This research includes two independent variables i.e. earnings management (based on discretionary accruals) and real earnings management, one dependent variable i.e. auditor's opinion, along with control variables. In the first main hypothesis the relation between real earnings management and auditor's opinion is examined; and the second hypothesis involves the association between discretionary accrual-based earnings management and auditor's opinion. In this research some 117 firms in the time period 2008-2013 are empirically investigated and studied using logistic regression method. In conclusion, the second and third hypotheses are rejected; however examination of the first and fourth hypotheses confirms their significant association with auditor's opinion.
\end{abstract}

Keywords: accrual-based earnings management, real earnings management, auditor's opinion

\section{Introduction}

Income reporting is one of the items in financial statements which is known as a criterion for performance evaluation and profitability of a business enterprise. Assessment of a business entity's net income depends upon different methods and accounting estimates. Managers' freedom and leverage in using principles of matching and realization, estimation, and forecast alongside application of techniques such as changing inventory taking and evaluation methods, amortization of goodwill, assuming costs of research and development as current or capitalized cost, and determining bad debts expenses are instances by which managers can manipulate and manage the earnings and income. On one hand, due to managers' awareness of the firm's situation they are expected to present information in a way that best reflect the company's condition. On the other hand, personal motives such as trying to maintain their position in the firm, receiving rewards, and etc. managers of business enterprises may unwittingly or otherwise try to make the firm look good by manipulating the income reporting. In a situation like this, there is a discrepancy between real earnings and reported earnings in financial statements, and earnings management is said to have been carried out (Nezami, 2011).

On the other hand, quality of auditor's performance depends on numerous factors such as auditor's capabilities (including knowledge, experience, comparison and matching ability, and technical efficiency) and professional execution (including independence, due professional care, conflict of interests, and judgment) (Namazi \& Bayazidi, 2008).

When it comes to firms which constantly report their earnings, whether how much of that earning is real and how much is managed is of interest both to investors and auditors.

After the Enron incident, the concept of earnings management has become a vital issue and attracted a lot of attention.

Therefore, the main question in this research is: what is the relationship between earnings management based on discretionary accruals and real earnings management and auditor's opinion? 


\section{Theoretical Basis}

Earnings management is the process of taking general measures in the acceptable domain of accounting which helps accomplish private gain and present the desired level of profit. Earnings management generally covers a wide spectrum of actions which influence the earnings (Gestaler \& Amas, 1998).

Concerning supervision over management's financial authorities, this is the auditing committee which protects the investors by keeping the credibility of a firm's financial statements in check. In fact, the role of auditor is to make sure that financial reporting has a high quality. The auditing committee is the final supervisor of financial reporting; it is its job to reduce opportunistic management of earnings via different means and methods (Ebrahimi Kordlar \& Seyedi, 2008). The general purpose of this article is to study the relationship between earning management and auditor's opinion. Different studies have yielded different results. Of course different criteria have been relied upon in order for assessment of earnings management, which in turn would have lead to difference in the obtained results. In general, with earnings management done by managers, it is expected that the audit report is modified (unqualified).

Dechowdhury (2006) defines real earnings management as follows:

"Deviation from normal operational activities by managers in order to confuse the stakeholders as to whether the goals of financial reporting have been met through normal operational procedures."

Managers who are widely involved with such activities tend further toward real earnings management, because, such activities can influence the income and profits of the current period. Despite enabling managers to realize the goals of financial reporting, these deviations however do not increase the firm's value (Saeedi \& Hamidian, 2013, the relationship between real earnings management activities and future performance in companies listed in Tehran stock exchange).

The studies reveal two major methods of earnings management. Firm managers can manipulate accruals as well as real activities to manage earnings (Healy et al., 1999). Earnings management literature mainly emphasizes accrual-based earnings management, while little studies have been conducted on real earnings management and its impact on the performance of a business enterprise.

Real earnings management is accompanied by a change in timing schedule or the structure of real activities of a business entity. Hence, researchers who study real earnings management seek to identify abnormal levels activity in business enterprises.

\section{Research History}

\subsection{Domestic Studies}

Izadinia et al. (2013) have studies the relationship between financial leverage and real earnings management in companies listed in Tehran stock exchange. In their study, 118 firms in the time period of 2000-2010 have been investigated. The criteria of real earnings management in their study include abnormal operational cash flow, abnormal production costs, and abnormal discretionary costs. The real earnings management is the dependent variable, while financial leverage is the independent variable. In order to study the relationship between financial leverage and criteria of real earnings management, multivariate regression analysis based on combined data has been used. The results have indicated that there is a reverse and significant relationship between financial leverage and criteria of real earnings management.

Patoyi and Abshizini (2013) have studied the relation between real earnings management and earnings accounting management from income smoothing standpoint. The cash flow from operating activities represents real earnings management, and discretionary accruals represent earnings accounting management. In this study some 110 companies listed in Tehran stock exchange in the time period 2001-2008 have been investigated. To test the hypothesis the real earnings management and earnings accounting management estimations proposed in the model by Roychowdhury (2006) and Kothari et al. (2005) have been used. The results indicate that managers tend to use both methods of earnings management for income smoothing; real earnings management and earnings accounting management are carried out simultaneously.

Saeedi et al. (2013) studied the relationship between real earnings management activities and future performance in companies listed in Tehran stock exchange. In this research 123 firms in a 9-year time period (2000-2009) have been studied and the criteria of real earnings management proposed by Zarowin and Cohen (2010) have been used. Also future cash flow from operation and future operating gains are considered as the criteria of future performance. The results indicate that there is a reverse and significant relation between criteria of real earnings management and future performance. In other words, manipulation of real activities in the current 
period will reduce the future performance of the firm.

Nownahal Nahr et al. (2013) studied the impact of auditing quality on earnings management in recently listed companies in Tehran stock exchange. In order to determine auditing quality, two criteria of auditing institution size and auditor tenure have been used. In order to assess earnings management as the dependent variable, the Jones adjusted model has been used. Also firm size, financial leverage, and cash flow from operation are considered as control variables. In this research 50 companies in the time period between 2003 and 2010 have been investigated. The results of this study -without putting the control variables into consideration- reveal that larger audit firm and longer audit tenure have negative impact on earnings management. However, as the control variables enter the equation, the results indicate that larger audit firms have no impact on earnings management and longer audit tenure has negative effect on earnings management in companies recently listed in Tehran stock exchange.

Bahar Moghadam and Hasani Fard (2010) have studied the relationship between financial events and earnings management in companies listed in Tehran stock exchange. Manipulation of real financial events is done by focusing on variables such as cash flow from operations, discretionary costs, changing the inventory and production costs. 40 companies in the time period 1999-2006 have been studied. The results reveal that there is a significant relation between cash flow from operations and change in the inventory on one hand, and earnings management in listed companies in Tehran stock exchange on the other hand.

\subsection{Foreign Studies}

In a study titled "consequences of earnings management and weak corporate governance: evidence from cash holdings", Greiner (2013) used Gunny (2010) and Roychowdhury (2006) criteria for assessment of real earnings management, and Opler et al. (1999) model for estimation of cash holdings. The results reveal that real earnings management negatively affects stockholders' evaluation of cash holdings, while strong corporate governance mechanisms improve their evaluation.

Zhao et al. (2012) have studied the impact of take-over protection on real earnings management and firm's future performance. They have studied 7966 firms in the time period 1995-2008. The comprehensive model of real earnings management has been used to estimate real earnings management. The results reveal that firms which are less monitored for ownership take-over have higher levels of real earnings management; such firms have lower operating performances.

Chi et al. (2011) have studied the relation between audit quality and real earnings management. In this study, auditor's expertise in the industry is considered as the indicator of audit quality, and comprehensive model of real earnings management is used to estimate real earnings management. The results have indicated that presence of large and famous audit organizations increases real earnings management. They have stressed out that increased scrutiny by large audit organizations reduces firm's accounting flexibility. Therefor firms which are audited by large-scale audit organizations are more probable to manipulate real activities. They also express that audit quality is related to higher levels of real earnings management and point out that high levels of audit quality could have unwanted consequences. Supervisory institutions such as board of directors and audit committee should take the consequences of high-quality auditors which would lead to manipulation of real activities into consideration.

\section{Research Hypotheses}

Hypothesis 1: There is a significant relation between real earnings management and audit opinion.

Hypothesis 1.1: There is a significant relation between abnormal cash flow from operations (as a criterion for real earnings management) and audit opinion.

Hypothesis 1.2: There is a significant relation between abnormal production costs (as a criterion for real earnings management) and audit opinion.

Hypothesis 1.3: There is a significant relation between abnormal discretionary costs (as a criterion for real earnings management) and audit opinion.

Hypothesis 2: There is a significant relation between earnings management based on discretionary accruals and audit opinion.

\section{Research Variables}

Independent variable: In order to test the hypotheses in this study, earnings management (manipulation of real activities or discretionary accruals) is considered as the independent variable. 
Dependent variable: the audit opinion is considered as the dependent variable of this study.

\section{Calculating the dependent variable:}

AO equals 1 if the opinion is qualified, and 0 if it is not.

\section{Calculating the independent variable:}

\section{A: Earnings management (discretionary accruals)}

In this study, based on Jones adjusted model, discretionary accruals (DA) is considered as the criterion for earnings management. For assessment of discretionary accruals the following steps have been taken.

1- Fist the total accruals (TA) of the firm in the studied year have been calculated. In order to calculate the accruals this study uses Jones adjusted model (Dechow et al. 1995) in the following manner:

$$
T A_{i t}=E_{i t}-O C F_{i t}
$$

2- Then using the least squares method, the non-discretionary accruals are calculated as below:

$$
N D A_{i t}=\alpha_{1}\left(\frac{1}{A_{i(t-1)}}\right)+\alpha_{2}\left(\frac{\square R E V_{i t}-\square R E C_{i t}}{A_{i(t-1)}}\right)+\alpha_{3}\left(\frac{P P E_{i t}}{A_{i(t-1)}}\right)
$$

After assessment of non discretionary accruals, the discretionary accruals as the criterion for the variable of earnings management -based on Jones adjusted model- are estimated as below.

$$
D A_{i t}=\left(\frac{T A_{i t}}{A_{i(t-1)}}\right)-N D A_{i t}
$$

\section{B: Earnings management (manipulation of real activities)}

In order to assess real earnings management Roychowdhury (2006) method has been employed. Similar to his study, the present research uses three criteria to study manipulation of real activities: abnormal cash flow from operations, abnormal discretionary costs, and abnormal production costs.

In this study, first the abnormal levels of cash flow from operation, abnormal discretionary costs, and abnormal production costs have been calculated using the expanded Dechow (1998) model, similar to the study by Roychowdhury (2006).

$$
\left(C F O_{i t} / A_{i, t-1}\right)=k_{0}+k_{l t}\left(1 / A_{i, t-1}\right)+k_{2}\left(S_{i t} / A_{i, t-1}\right)+k_{3}\left(\Delta S i t / A_{i, t-1}\right)+\varepsilon_{i t}
$$

Abnormal cash flow from operation equals cash flow from operations minus normal level of cash flow from operation, which is calculated using estimated coefficients in model (1).

Production cost is defined as the sum of the cost of sold goods and change in goods and material inventory during the year. In this study, the cost of sold goods is expressed as a linear function of contemporaneous sales.

$$
\left(\operatorname{Prod}_{i t} / A_{i, t-1}\right)=k_{0}+k_{1 t}\left(1 / A_{i, t-1}\right)+k_{2}\left(S_{i t} / A_{i, t-1}\right)+k_{3}\left(\Delta S_{i t} / A_{i, t-1}\right)+k 4\left(\Delta S_{i, t-1} / A_{i, t-1}\right)+\varepsilon_{i t}
$$

Discretionary expenses should be also expressed as a linear function of contemporaneous sales:

$$
\left.\left(\text { DiscExpit } / A_{i, t-1}\right)=k 0+k 1 t\left(1 / A_{i, t-1}\right)+k 2\left(\text { Sit } / A_{i, t-1}\right)+\varepsilon_{i t}\right)
$$

Abnormal cash flow from operations (R-CFO), abnormal production expenses (R-PROD), and abnormal discretionary expenses (R-DISX) are the difference of real values and values predicted by the above models.

Control variables:

BIG, ROA, TLE, and LAO.

BIG: if the auditor is a member of one of the four large audit organizations, its value equals 1 , otherwise it is 0 .

ROA (return-on-assets):

If the firm has started working in the contemporaneous year, ROA can be calculated assuming that the book value of a firm's assets which comes from investments will return in a few years.

ROA= Net income/ Total Assets

TLE (leverage ratio): leverage ratio is used to evaluate a firm's financial risk. It is calculated by dividing the total debt by stockholders' equity. In other words it is the debt equity ratio.

LAO: Dummy variable; equals 1 if the firm has received a qualified opinion in the last year, 0 otherwise.

The following is the model used in this study to test the hypothesis 1 : 


$$
A O_{i t}=B_{0}+B_{1} R E M_{i t}+B_{2} B I G N_{i t}+B_{3} R O A_{i t}+B_{4} T L E_{i t}+B_{5} L A O_{i t-1}+E_{i}
$$

Wherein:

$$
R E M i, t=(\text { AbnCFOi, } t+\text { AbnProdCosti,t }+ \text { AbnDisExpi,t })
$$

$\mathrm{AbnCFO}_{\mathrm{it}}=$ abnormal cash flow from operations

AbnProdCost $_{\mathrm{it}}=$ abnormal production costs

AbnDisExp $\mathrm{it}_{\mathrm{it}}=$ abnormal discretionary expenses

Also the following is the model used in this study to test the hypothesis 2 :

$$
A O_{i t}=B_{0}+B_{1} A M_{i t}+B_{2} B I G N_{i t}+B_{3} R O A_{i t}+B_{4} T L E_{i t}+B_{5} L A O_{i t-1}+E_{i}
$$

Wherein:

(AMit=DAit) for the firm (i) in the fiscal year (t).

\section{Methodology}

This is an experimental research which is classified as applied study. The data required for analysis and hypothesis examination has been collected from financial statements of companies listed in Tehran stock exchange for a 6-year time period. In the end, the data is subject to correlation analysis.

\subsection{Methods of Data Collection}

To collect the theoretical information, books, theses, and related articles have been referred to via internet and libraries. In order to collect the data the website www.rdis.ir has been referred to; also Rahavar-e-Novin software program has been used.

\subsection{Statistical Population and Sample}

The statistical population of the present study is consisted of companies listed in Tehran stock exchange which have the following qualifications:

1) The company should not be an intermediary or investment firm. This study is concerned with non-financial firms, hence, banks and all investment firms are eliminated from the sample.

2) The company's stocks should have been sold and exchanged in the time period between April 2008 and March 2014.

\section{Analysis of the Results}

\begin{tabular}{|c|c|c|c|c|c|c|}
\hline \multicolumn{7}{|c|}{$\begin{array}{l}\text { Date: 09/02/15 Time: } 11: 42 \\
\text { Sample: } 13871392\end{array}$} \\
\hline TLE & ROA & PRODASS & DISXASS & DA & CFOASS & \\
\hline 1.732284 & 0.234985 & 0.033782 & 0.208682 & 0.011079 & 0.041435 & Mean \\
\hline 0.827525 & 0.141631 & 0.033658 & 0.206376 & 0.028648 & 0.040132 & Median \\
\hline 58.9835 & 2.699139 & 0.047548 & 0.319907 & 0.053076 & 0.206563 & Maximum \\
\hline 0.176298 & 0.001322 & 0.31069 & 0.180163 & -0.638889 & -0.232743 & Minimum \\
\hline 5.589014 & 0.357818 & 0.001071 & 0.019820 & 0.073623 & 0.045822 & Std. Dev. \\
\hline 9.341416 & 4.395277 & 8.686818 & 1.780710 & -6.363762 & -1.364665 & Skewness \\
\hline 94.67698 & 26.48220 & 92.59433 & 9.799903 & 52.65253 & 12.17076 & Kurtosis \\
\hline 256046.2 & 183389.11 & 243622.9 & 1723.480 & 76850.39 & 2677.900 & Jarque-Bera \\
\hline 0.000000 & 0.000000 & 0.000000 & 0.000000 & 0.000000 & 0.000000 & Probability \\
\hline 702 & 702 & 702 & 702 & 702 & 702 & Observations \\
\hline
\end{tabular}

\subsection{Descriptive Statistics}

Table 1. Descriptive statistics of the research data

\subsection{Inferential Statistics}

\subsubsection{Jarque-Bera Test}

In order to examine the normal distribution of dependent variable, the Jarque-Bera test has been employed. The dependent variable has been examined by this test and the result indicates the non-normal distribution of dependent variable (lack of information symmetry). The output of Jarque-Bera test produced by Eviews software 
is displayed in Figure 1.

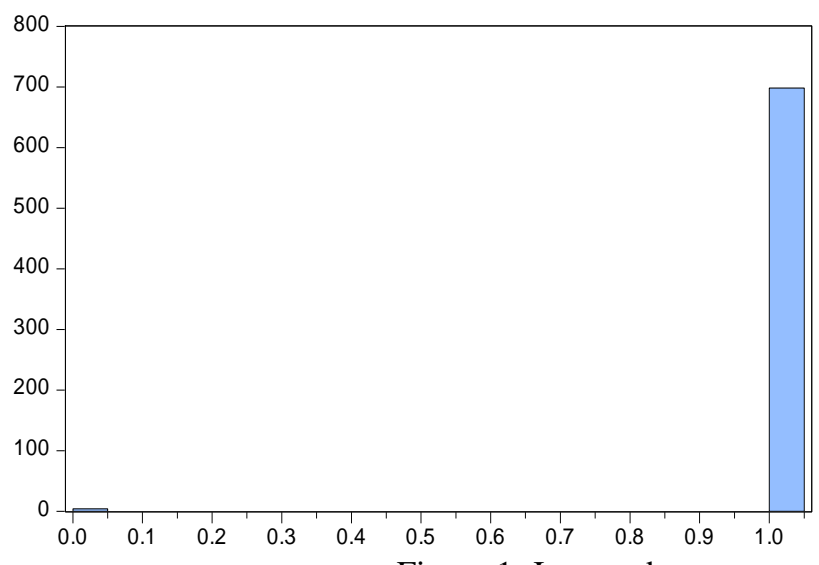

\begin{tabular}{|c|c|}
\hline \multicolumn{2}{|c|}{$\begin{array}{l}\text { Series: AO } \\
\text { Sample } 13871392 \\
\text { Observations } 702\end{array}$} \\
\hline Mean & 0.994302 \\
\hline Median & 1.000000 \\
\hline Maximum & 1.000000 \\
\hline Minimum & 0.000000 \\
\hline Std. Dev. & 0.075323 \\
\hline Skewness & -13.13414 \\
\hline Kurtosis & 173.5057 \\
\hline Jarque-Bera & 870545.1 \\
\hline Probability & 0.000000 \\
\hline
\end{tabular}

Figure 1. Jarques-bera test

\section{Testing the stationary of variables}

Table 2. Dickey-Fuller unit root test

\begin{tabular}{ccccccc}
\hline TLE & prodass & DISXASS & CFOASS & ROA & DA & variable \\
\hline-12.16 & -31.39 & -23.88 & -11.11 & -9.62 & -24.46 & W-stat \\
0.000 & 0.000 & 0.000 & 0.000 & 0.008 & 0.000 & p-value \\
\hline
\end{tabular}

\section{Results of regression model fitting}

In order to test the hypotheses of this study, the following regression model has been used:

$$
A O_{i t}=B_{0}+B_{1} R E M_{i t}+B_{2} B I G N_{i t}+B_{3} R O A_{i t}+B_{4} T L E_{i t}+B_{5} L A O_{i t-1}+E_{i}
$$

After testing and confirmation of regression assumptions, the results of regression model fitting are demonstrated in Table 3. The value of Chi-square statistic (9.29) points out to the significance of the regression model. The coefficient of determination is $18 \%$; this means that in this regression equation, only $18 \%$ of the change in audit opinion is explained by independent and control variables. In this table, the positive (negative) values demonstrated in the coefficient column indicate the direct (reverse) impact of the corresponding variable on the auditor's opinion.

Table 3. Results of regression model fitting

\begin{tabular}{ccccc}
\hline Prob. & z-Statistic & Std. Error & Coefficient & Variable \\
\hline 0.0223 & -2.639869 & 235.0047 & -618.4794 & CFOASS \\
0.2258 & 1.211317 & 958.1659 & 1160.643 & DISXASS \\
0.2189 & -1.229503 & 2749.84 & -3380.942 & PRODASS \\
0.3857 & 0.867491 & 1.182678 & 1.025962 & BIG \\
0.8252 & 0.220868 & 5.448800 & 1.202805 & ROA \\
0.1716 & 1.366958 & 3.150616 & 4.306752 & TLE \\
0.8760 & -0.156074 & 1.045035 & -0.163103 & LAO \\
0.2558 & -1.136380 & 83.05077 & -94.37722 & C \\
0.994302 & Mean dependent var & 0.188452 & McFadden R-squared \\
0.075342 & S.E. of regression & 0.075323 & S.D. dependent var \\
3.939419 & Sum squared resid & 0.079806 & Akaike info criterion \\
-20.01207 & Log likelihood & 0.131703 & Schwarz criterion \\
40.02414 & Deviance & 0.099865 & Hannan-Quinn criter. \\
-24.65914 & Restr. log likelihood & 49.31828 & Restr. Deviance \\
-0.028507 & Avg. log likelihood & 9.294135 & LR statistic \\
& & 0.0232223 & Prob(LR statistic) \\
\hline 702 & \multicolumn{7}{c}{ Total obs } & Obs with Dep=0 \\
& & 698 & Obs with Dep=1 \\
\hline
\end{tabular}




\section{Judgment and Evaluation}

Considering the obtained values of Wald statistic and significance level, the variable of abnormal cash flow from operations affects the auditor's opinion. That is because the significance level for this variable equals 0.023 (less than 0.05 ) and also the absolute value of the Wald statistic equals 2.63 , which is greater than 1.96 . The value of the coefficient for this independent variable has a negative sign which indicates its reverse impact on the dependent variable.

1) The variable of abnormal discretionary expenses does not affect the auditor's opinion. That is because the obtained significance level for this variable equals 0.22 (greater than 0.05 ) and also the absolute value of the Wald statistic equals 1.21, which is smaller than 1.96.

2) The variable of abnormal production costs does not affect the auditor's opinion. That is because the obtained significance level for this variable equals 0.22 (greater than 0.05 ) and also the absolute value of the Wald statistic equals 1.22 , which is smaller than 1.96 .

3) The variable of audit organization size does not affect the auditor's opinion. That is because the obtained significance level for this variable equals 0.38 (greater than 0.05 ) and also the absolute value of the Wald statistic equals 1.86 , which is smaller than 1.96 .

4) The variable of return-on-assets ROA does not affect the auditor's opinion. That is because the obtained significance level for this variable equals 0.82 (greater than 0.05 ) and also the absolute value of the Wald statistic equals 0.22 , which is smaller than 1.96 .

5) The variable of leverage ratio TLE does not affect the auditor's opinion. That is because the obtained significance level for this variable equals 0.17 (greater than 0.05 ) and also the absolute value of the Wald statistic equals 1.36 , which is smaller than 1.96 .

6) The dummy variable of LAO does not affect the auditor's opinion. That is because the obtained significance level for this variable equals 0.87 (greater than 0.05) and also the absolute value of the Wald statistic equals 0.15 , which is smaller than 1.96 .

\section{Results of the regression model fitting}

In order to test the hypotheses of this study, the following regression model has been used:

$$
A O_{i t}=B_{0}+B_{1} A M_{i t}+B_{2} B I G N_{i t}+B_{3} R O A_{i t}+B_{4} T L E_{i t}+B_{5} L A O_{i t-1}+E_{i}
$$

After testing and confirmation of regression assumptions, the results of regression model fitting are demonstrated in Table 4. The value of Chi-square statistic (6.39) points out to the significance of the regression model. The coefficient of determination is $13 \%$; this means that in this regression equation, only $13 \%$ of the change in audit opinion is explained by independent and control variables.

Table 4. Results of regression model fitting

\begin{tabular}{ccccc}
\hline Prob. & z-Statistic & Std. Error & Coefficient & Variable \\
\hline 0.0421 & -2.325297 & 13.81459 & -32.06257 & DA \\
0.3944 & 0.851754 & 1.176530 & 1.002114 & BIG \\
0.9635 & 0.045773 & 4.256955 & 0.194855 & ROA \\
0.0912 & 1.689325 & 2.847860 & 4.812481 & TLE \\
0.8816 & -0.148994 & 1.017430 & -0.151591 & LAO \\
0.3024 & 1.031341 & 2.281003 & 2.352492 & C \\
0.994302 & Mean dependent var & 0.129652 & McFadden R-squared \\
0.074966 & S.E. of regression & 0.075323 & S.D. dependent var \\
3.911415 & Sum squared resid & 0.078239 & Akaike info criterion \\
-21.46203 & Log likelihood & 0.117162 & Schwarz criterion \\
42.92407 & Deviance & 0.093283 & Hannan-Quinn criter. \\
-24.65914 & Restr. log likelihood & 49.31828 & Restr. Deviance \\
-0.030573 & Avg. log likelihood & 6.394210 & LR statistic \\
& & 0.026973 & Prob(LR statistic) \\
\hline 702 & Total obs & 4 & Obs with Dep=0 \\
& & 698 & Obs with Dep=1 \\
\hline
\end{tabular}




\section{Judgment and evaluation}

1) The variable of discretionary accruals affects the auditor's opinion. That is because the significance level for this variable equals 0.042 (less than 0.05) and also the absolute value of the Wald statistic equals 2.32, which is greater than 1.96. The value of the coefficient for this independent variable has a negative sign which indicates its reverse impact on the dependent variable.

2) The variable of auditor's size (large-scale auditor) does not affect the auditor's opinion. That is because the obtained significance level for this variable equals 0.39 (greater than 0.05 ) and also the absolute value of the Wald statistic equals 0.85, which is smaller than 1.96.

3) The variable of return-on-assets does not affect the auditor's opinion. That is because the obtained significance level for this variable equals 0.96 (greater than 0.05 ) and also the absolute value of the Wald statistic equals 0.045 , which is smaller than 1.96 .

4) The variable of leverage ratio does not affect the auditor's opinion. That is because the obtained significance level for this variable equals 0.091 (greater than 0.05) and also the absolute value of the Wald statistic equals 1.68 , which is smaller than 1.96 .

5) The dummy variable of LAO does not affect the auditor's opinion. That is because the obtained significance level for this variable equals 0.88 (greater than 0.05 ) and also the absolute value of the Wald statistic equals 0.14 , which is smaller than 1.96 .

\section{Examination of the hypotheses}

The first hypothesis: there is a significant relationship between abnormal cash flow from operations and auditor's opinion.

According to Table 3, the main hypothesis is confirmed.

The second hypothesis: there is a significant relationship between abnormal production costs and auditor's opinion.

According to Table 3, the variable of abnormal production costs does not affect the auditor's opinion.

The third hypothesis: there is a significant relationship between abnormal discretionary expenses and auditor's opinion.

According to Table 3, the variable of abnormal discretionary expenses does not affect the auditor's opinion.

The fourth hypothesis: there is a significant relationship earnings management based on discretionary accruals and auditor's opinion.

According to Table 4, the variable of discretionary accruals affects the auditor's opinion. The value of the coefficient for this independent variable has a negative sign which indicates its reverse impact on the dependent variable.

\section{Conclusion}

In order to study the relationship between earnings management (real and accrual-based) and auditor's opinion in this research, numerous variables have been presented and analyzed for the purpose of hypothesis examination. The results reveal that only discretionary accruals and abnormal cash flow from operations have a significant relationship with auditor's opinion. These results are in alignment with those obtained by some studies in other countries.

Butler, Leone, and Willenborg (2004) support this view. They have concluded that it is improbable that auditors issue qualified opinion for earnings management reasons. To be exact, they have investigated 7000 qualified opinions about U.S commercial firms from 1994 to 1999, and tested the relationship between abnormal accruals and auditors' opinion. After thorough investigation of the accruals, they have concluded that there is a negative relationship between accruals and qualified opinion.

Herbohn and Ragunathan (2008) have investigated whether a negative association exists between actual abnormal accruals and the possibility of receiving a qualified audit opinion in Australia. They have concentrated on a sample of firms listed on the Australian Stock Exchange in the time period 1999-2003. Similar to the study by Butler et al. (2004), they have reported a negative relationship between the probability of receiving a qualified opinion and accruals.

However, there are no considerable instances of domestic studies on the relationship between real earnings management and auditor's opinion. 


\section{Suggestions}

\subsection{Suggestions Based on the Findings of the Present Research}

Considering the findings of the present research and other similar studies, users of financial statements especially the investors are advised to take the discussed issues into consideration before making any investment-related decisions.

\subsection{Suggestions to Researchers}

Conducting a similar study using firms' interim financial statements.

Examination of the present research using the financial statements of the firms in OTC market.

Swapping the dependent and independent variables and re-testing their association and relationship.

Using other control variables (firm's profitability, number of years during which the firm's stocks has been exchanged, rating and ranking of the auditing firm in terms of income, the auditing firm's record and experience in audit) in order to study the relationship between earnings management and audit opinion type.

\section{Limitations}

1) Lack of adjustment of items of financial statements due to business units being founded in different times; this leads to a time difference for earning and acquiring assets and capital items which in turn reduces the comparability of the items and limits the possibility of generalizing the results of this study.

2) The statistical population of the present study is consisted of only some of the active firms in stock exchange; therefore these results can not be generalized and applied to other countries.

\section{References}

Abedi, M. (2007). Role of accruals in earnings forecast and future cash flows. M.A thesis, Neshabour Islamic Azad University.

Ahmadpour, A. (2009). A study of the role of dormant member of board of directors and institutional investors in earnings management behavior based on threshold model. Accounting Researches, 16(58), 1-20.

Arnedo, L., Lizarraga, F., \& Sanchez, S. (2008). Discretionary accruals and auditor behavior in code-law contexts: An application to failing Spanish firms. European Accounting Review, 17(4), 641-66.

Audit Organization. (2014). Iranian Audit standards. Retrieved from http://ww.audit.org.ir

Banimahd, B., Hasasyegane, Y., \& Yazdanian, N. (2014). Earning management and audit opinion: Evidence from private sector. Management Accounting, 7(2), 17-32.

Bartov, E., Gul, F. A., \& Tsui, J. S. L. (2001). Discretionary-accruals models and audit qualifications. Journal of Accounting and Economics, 30(3), 421-452.

Bolou, G., \& Hosseini, A. (2007). Earnings management and its measurement: Theoretical approach. Official Accountant Magazine, (12), 72-88.

Bradshaw, M. T., Richardson, S. A., \& Sloan, R. G. (2001). Do analysts and auditors use information in accruals? Journal of Accounting Research, 39(1), 45-74.

Butler, M., Leone, A. J., \& Willenborg, M. (2004). An empirical analysis of auditor reporting.

DeAngelo, H., DeAngelo, L., \& Skinner, D. J. (1994). Accounting choice in troubled companies. Journal of Accounting and Economics, 17, 113-143.

Dechow, P., \& Dichev, I. (2002). The quality of accruals and earnings: The role of accrual estimation errors. Accounting Review, 77(Suppl.), 35-59.

Ebrahimi, K. A., \& Hasani, A. E. (2006). Study of earnings management in initial public offering in companies listed in Tehran stock exchange. Accounting and Auditing Studies, (45).

Ebrahimi, K. A., \& Seyedi, A. (2008). The role of independent auditors in reducing discretionary accruals. Accounting and Auditing Studies, 15(54), 3-16.

Francis, J. R., \& Krishnan, J. (1999). Accounting accruals and auditor reporting conservatism. Contemporary Accounting Research, 16(1), 135-165.

Herbohn, K., \& Ragunathan, V. (2008). Auditor reporting and earnings management: Some additional evidence. Accounting and Finance, 48, 575-601. 
Khodadadi, V., \& Janjani, R. (2010). Study of the relationship between earnings management and firm's profitability in companies listed in Tehran stock exchange. Studies of Financial Accounting, 3(7), 77-96.

Lam, K. C. K., \& Mensah, Y. M. (2006). Auditors' decision-making under going-concern uncertainties in low litigation-risk environments: Evidence fromHong Kong. Journal of Accounting and Public Policy, 25, 706-739.

Nezami. (2011). The impact of ownership structure on earnings quality in companies listed in Tehran stock exchange. M.A thesis, Sistan \& Baluchistan University.

Noorvash, I., Sepasi, S., \& Nikbakht, M. (2005). Study of earnings management in companies listed in Tehran stock exchange. Shiraz University Social Sciences and Humanities Magazine, 22(2).

Roychowdhury, S. (2006). Earnings management through real activitiesmanipulation. Journal of Accounting and Economics, 42(December), 335-370.

Technical committee of Iran's Audit Organization. (2000). Auditing standards: Principles and regulations of accounting and auditing (p. 124). Tehran, Iran's Audit Organization.

Tsipouridoua, \& Spathisb, (2014). Audit opinion and earnings management: Evidence from Greece. Accounting Forum, 38, 38.

Zang, A. (2007). Evidence on the tradeoff between real manipulation and accrual manipulation. Workingpaper. University of Rochester.

\section{Copyrights}

Copyright for this article is retained by the author(s), with first publication rights granted to the journal.

This is an open-access article distributed under the terms and conditions of the Creative Commons Attribution license (http://creativecommons.org/licenses/by/3.0/). 